\title{
The size of the chromosome of Azotobacter chroococcum
}

\author{
Adhar C. Manna and H. K. Das \\ Author for correspondence: H. K. Das. Tel: +9111 661044. Fax: +91116865886. \\ e-mail: uunet!shakti!vikram!jnuniv!hiren
}

Genetic Engineering Unit, Centre for Biotechnology, Jawaharlal Nehru University, New Delhi - 110067, India

\author{
The DNA of Azotobacter chroococcum M4 was digested with rare-cutter \\ restriction endonucleases $A$ sel and $D$ ral and restriction fragments were \\ separated by pulsed-field gel electrophoresis. The chromosome size was \\ estimated to be around $5300 \mathrm{~kb}$ by summing the sizes of the resolved \\ restriction fragments.
}

Keywords: Azotobacter cbroococcum, chromosome size, pulsed-field gel electrophoresis

\begin{abstract}
Azotobacter vinelandii and Azotobacter chroococcum are aerobic, nitrogen-fixing bacteria with multiple chromosomes: A. vinelandii UW can contain 40-80 chromosome copies (Sadoff et al., 1979; Nagpal et al., 1989). The chromosome size of $A$. vinelandii has been determined to be around $4500 \mathrm{~kb}$ by pulsed-field gel electrophoresis (PFGE) (Manna \& Das, 1993). The E. coli chromosome is about $4700 \mathrm{~kb}$ in size (Smith et al., 1987).
\end{abstract}

PFGE allows the resolution of large DNA molecules and permits the accurate determination of chromosome size. We report here the use of this technique to estimate the size of the chromosome of $A$. chroococcum M4, a wild-type strain isolated from the rhizosphere of maize plants at the Indian Agricultural Research Institute, New Delhi (Apte \& Shende, 1981).

Growth of cells, embedding, lysis and digestion with restriction endonucleases for PFGE were done as described by Manna \& Das (1993). The DNA bands from agarose gels were transferred to nitrocellulose membranes according to Sambrook et al. (1989). The DNA fragment which was to be used as probe for hybridization was eluted from a low-melting-point agarose pulsed-field gel $(1 \cdot 0 \%, \mathrm{w} / \mathrm{v})$. The fragment was radiolabelled by using random primers (Feinberg \& Vogelstein, 1983) and Southern hybridization was performed as described in Sambrook et al. (1989).

Accurate measurement of genome size by PFGE relies on the ability to resolve the fragments upon electrophoresis; this requires restriction endonucleases that cleave infrequently. The genomes of Azotobacter species have $\mathrm{G}+\mathrm{C}$ contents in the range 64.8 to $66.7 \mathrm{~mol} \%$ (Robson et al., 1984); thus enzymes that recognize only A-T sequences may cleave infrequently. A. chroococcum DNA was digested with AseI, DraI, $S_{s p \mathrm{I}}$ and $S p e \mathrm{I}$ (New

Abbreviation: PFGE, pulsed-field gel electrophoresis.
England Biolabs) and the fragments were separated by PFGE. $S_{s p \text { I }}$ and $S p e$ I yielded too many fragments of less than $150 \mathrm{~kb}$ (data not shown). AseI and DraI generated 7 and 20 bands, respectively (Fig. 1a). When undigested A. cbroococcum DNA was subjected to PFGE, all the DNA remained in the well during electrophoresis (Fig. 1a, lane 1 ), indicating that the $A$. chroococcum genome was intact, and no shearing or degradation of DNA occurred during the preparation, storage or electrophoresis. When $A$. vinelandii chromosomal DNA was digested with AseI or DraI and separated by PFGE, more than 30 fragments were visible (unpublished results), which had very little similarity with those from $A$. chroococcum.

The sizes of the bands of AseI and DraI digest of $A$. chroococcum DNA, estimated using yeast chromosomes and $\lambda$ DNA concatemer markers (New England Biolabs), are given in Table 1. Sizes of large fragments were determined by graphical analysis of two-point linear interpolation (Heath et al., 1992). Logarithmic interpolation was used for smaller fragments.

The intensity of UV fluorescence of ethidium-bromidestained bands was determined by laser scanning (Pharmacia-LKB, Ultra-Scan XL) of polaroid photograph negatives. The fluorescence intensity of bands composed of linear DNA fragments in equimolar concentrations should increase with their size. Based on this principle, we plotted intensity (area under the peaks in the tracing) versus size $(\mathrm{kb})$ of the fragments generated by Ase I and DraI (data not shown). We inferred that band 9 of DraI digests comprised two DNA fragments of about $125 \mathrm{~kb}$, whereas all the other DraI bands comprised a single fragment. For the AseI digest, we concluded that bands 2, 4 and 6 comprised two DNA fragments each $(780,445$ and $140 \mathrm{~kb}$, respectively) and that band 5 consisted of three DNA fragments of about $350 \mathrm{~kb}$.

Complete digestion of $A$. chroococcum DNA with AseI and DraI was confirmed by Southern hybridization using the 
(a)

(b)

(c)

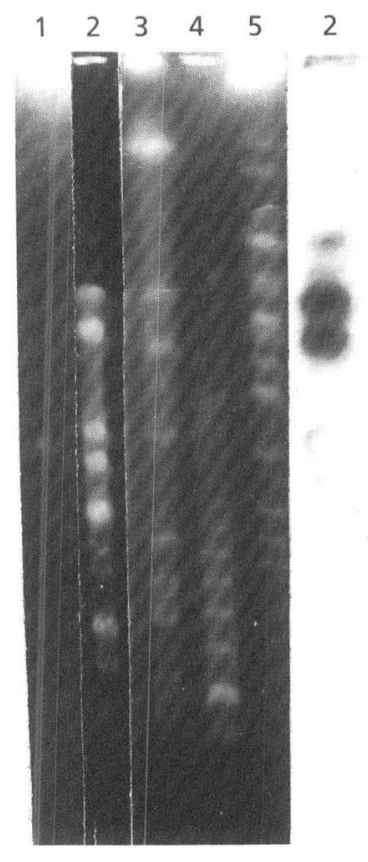
3

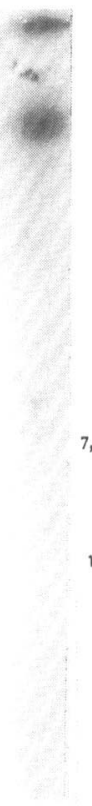

$2 \quad 3 \quad 4$

5

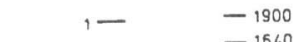

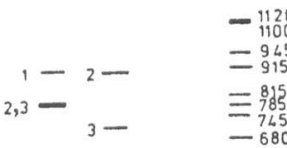

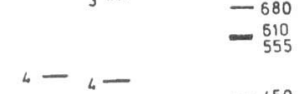

Fig. 1. PFGE of $A$. chroococcum M4 DNA. Electrophoresis was in $1 \%$ agarose (PFGE grade, Sigma) in $50 \mathrm{mM}$ Tris/borate, $0.1 \mathrm{mM}$ EDTA, $\mathrm{pH} 8.0$, at $200 \mathrm{~V}$ and $12-14^{\circ} \mathrm{C}$. Pulse times were $5 \mathrm{~s}$ to $120 \mathrm{~s}$ for $20 \mathrm{~h}$ for the experiment shown in lane 1 , and $5 \mathrm{~s}$ to $100 \mathrm{~s}$ for $18 \mathrm{~h}$ followed by $120 \mathrm{~s}$ for $4 \mathrm{~h}$ for all others. (a) Lane 1, undigested $A$. chroococcum DNA; lane 2, Asel digest; lane 3, Dral digest; lane 4, low-range PFG marker DNA; lane 5 , Saccharomyces cerevisiae YPH80 chromosomes. (b) Autoradiogram of Southern hybridization blot of lanes 2 and 3 of (a) using the $1690 \mathrm{~kb}$ Dral DNA fragment as probe. (c) Schematic interpretation of bands in lanes $2-5$ of (a). Doublets or triplets are indicated with thicker bands. Sizes are given in kb.

$1690 \mathrm{~kb}$ DraI DNA fragment as $\alpha_{-}{ }^{32} \mathrm{P}$-labelled radioactive probe. Among the fragments generated by $D$ raI digestion, only the $1690 \mathrm{~kb}$ fragment hybridized (Fig. 1b, lane 3). The $930 \mathrm{~kb}$ and $780 \mathrm{~kb}$ bands of AseI digests also hybridized, suggesting that these had originated from the $1690 \mathrm{~kb} \mathrm{DraI}$ fragment. The intensity of the signals in the autoradiogram of AseI lane, as determined by laser scanning, confirmed the presence of two DNA fragments in band 2 of $A$ seI digests. Thus we estimate the size of the $A$. chroococcum chromosome to be $5296 \mathrm{~kb}$ based on the fragments generated by DraI digestion, and $5305 \mathrm{~kb}$ based on AseI digestion.

Our estimate of the size of the $A$. chroococcum chromosome is larger than that of Robson et al. (1984), who used twodimensional agarose gel electrophoresis to obtain size estimates of $1780 \mathrm{~kb}$ for $A$. chroococcum CW 8 and $1940 \mathrm{~kb}$ for $A$. chroococcum MCD-1. In their experiments the DNA was digested with the first restriction enzyme (EcoRI for CW8 and BstEII for MCD-1), electrophoresed in one direction and then digested in situ with the second enzyme (BstEII for CW8 and XhoI for MCD-1), and the fragments electrophoresed in the second direction. The enzymes

Table 1. Sizes of fragments of the $A$. chroococcum chromosome produced by Dral and Asel

\begin{tabular}{|ccc|}
\hline Fragment & \multicolumn{2}{c|}{ Fragment size (kb)* } \\
\cline { 2 - 3 } no. & $\begin{array}{c}\text { DraI } \\
\text { digestion }\end{array}$ & $\begin{array}{c}\text { AseI } \\
\text { digestion }\end{array}$ \\
\hline & $1690 \pm 10$ & $930 \pm 10$ \\
1 & $880 \pm 10$ & $780 \pm 15$ \\
2 & $700 \pm 10$ & $780 \pm 15$ \\
3 & $485 \pm 5$ & $510 \pm 10$ \\
4 & $280 \pm 5$ & $445 \pm 5$ \\
5 & $190 \pm 5$ & $445 \pm 5$ \\
6 & $175 \pm 5$ & $350 \pm 5$ \\
7 & $145 \pm 5$ & $350 \pm 5$ \\
8 & $125 \pm 4$ & $350 \pm 5$ \\
9 & $125 \pm 4$ & $140 \pm 4$ \\
10 & $85 \pm 3$ & $140 \pm 4$ \\
11 & $83 \pm 3$ & $85 \pm 3$ \\
12 & $63 \pm 2$ & \\
13 & $60 \pm 2$ & \\
14 & $50 \pm 2$ & \\
15 & $48 \pm 2$ & \\
16 & $35 \pm 1$ & \\
17 & $25 \pm 1$ & \\
18 & $18 \pm 1$ & \\
19 & $13 \pm 1$ & \\
20 & $11 \pm 1$ & \\
21 & 5296 & 5305 \\
Total size of & & \\
chromosome & & \\
(kb) & & \\
\hline
\end{tabular}

* Means of five different experiments, $\pm \mathrm{SE}$.

used were not infrequent cutters. Many of the fragments were probably not resolved and hence the estimate of the total size was low.

\section{ACKNOWLEDGEMENTS}

This work was supported by the Department of Biotechnology. We would like to thank $\operatorname{Dr} \mathrm{S}$. T. Shende of the Indian Agricultural Research Institute, New Delhi, for providing us with the Azotobacter cbroococcum M4 strain. A.C. M. is obliged to the University Grants Commission for a fellowship.

\section{REFERENCES}

Apte, R. \& Shende, S. T. (1981). Studies on Azotobacter chroococcum. I. Morphological, biochemical and physical characteristics of Azotobacter chroococcum. Zentralbl Bakteriol Abt II 136, 548-554.

Feinberg, A. P. \& Vogelstein, B. (1983). A technique for radiolabelling DNA restriction endonuclease fragments to high specific activity. Anal Biochem 132, 6-13.

Heath, J. D., Perkins, J. D., Sharma, B. \& Weinstock, G. M. (1992). NotI genomic cleavage map of Eschericbia coli K12 strain MG1655. $J$ Bacteriol 174, 558-567.

Manna, A. C. \& Das, H. K. (1993). Determination of the size of the Azotobacter vinelandii chromosome. Mol \& Gen Genet 241, 719-722. 
Nagpal, P., Jafri, S., Reddy, M. A. \& Das, H. K. (1989). Multiple chromosomes of Azotobacter vinelandii. J Bacteriol 171, 3133-3138.

Robson, R. L., Chesshyre, J. A., Wheeler, C., Jowes, R., Woodley, P. R. \& Postgate, J. R. (1984). Genome size and complexity in Azotobacter chroococcum. J Gen Microbiol 130, 1603-1612.

Sadoff, H. L., Shimei, B. \& Ellis, S. (1979). Characterization of Azotobacter vinelandii deoxyribonucleic acid and folded chromosomes. J Bacteriol 138, 871-877.

Sambrook, J., Fritsch, E. F. \& Maniatis, T. (1989). Molecular Cloning: a Laboratory Manual, 2nd edn. Cold Spring Harbor, NY: Cold Spring Harbor Laboratory.

Smith, C. L., Econome, J. G., Schutt, A., KIco, S. \& Cantor, C. R. (1987). A physical map of the Escherichia coli K12 genome. Science 236, 1448-1453.

Received 8 September 1993; revised 6 December 1993; accepted 13 December 1993. 